Felicitas Meifert-Menhard

Playing the Text, Performing the Future 


\section{Narrating Futures}

Edited by

Christoph Bode

Volume 2 
Felicitas Meifert-Menhard

Playing the Text,

Performing the

Future

Future Narratives in Print and Digiture

DE GRUYTER 
ISBN 978-3-11-027213-0

e-ISBN 978-3-11-027239-0

\section{Library of Congress Cataloging-in-Publication Data}

A CIP catalog record for this book has been applied for at the Library of Congress.

\section{Bibliographic information published by the Deutsche Nationalbibliothek}

The Deutsche Nationalbibliothek lists this publication in the Deutsche Nationalbibliografie; detailed bibliographic data are available in the Internet at http://dnb.dnb.de.

(C) 2013 Walter de Gruyter GmbH, Berlin/Boston

Typesetting: PTP-Berlin Protago-TEX-Production GmbH, Berlin

Printing: Hubert \& Co. GmbH \& Co. KG, Göttingen

(2) Printed on acid-free paper

Printed in Germany

www.degruyter.com 